\title{
$\mathrm{SO}_{2}$ 와 다른 기체에 대한 PEG와 Glutaraldehyde가 혼합된 PEBAX 막의 투과 특성
}

\author{
조은혜 · 김광배 · 임지원 ${ }^{\dagger}$ \\ 한남대학교 화학공학과 \\ (2014년 1월 28일 접수, 2014년 5월 1일 수정, 2014년 5월 13일 채택)
}

\section{Transport Properties of PEBAX Blended Membranes with PEG and Glutaraldehyde for $\mathrm{SO}_{2}$ and Other Gases}

\author{
Eun Hye Cho, Kwang Bae Kim, and Ji Won Rhim ${ }^{\dagger}$ \\ Department of Chemical Engineering, Hannam University, 1646 Yuseongdae-ro, Yuseong-gu, Daejeon 305-811, Korea
}

(Received January 28, 2014; Revised May 1, 2014; Accepted May 13, 2014)

\begin{abstract}
초록: 분자량이 $400 \mathrm{~g} / \mathrm{mol}$ 인 poly(ethylene glycol)(PEG 400)을 poly(ether-block-amide) 1657(PEBAX 1657)와 혼합 을 통하여 막을 제조하였고, time-lag 법에 의해 $\mathrm{N}_{2}, \mathrm{O}_{2}, \mathrm{CH}_{4}, \mathrm{CO}_{2}$, 그리고 $\mathrm{SO}_{2}$ 기체에 대한 투과도를 테스트하였다. 투과특성은 막 내에서 기체분자이동에 어느 것이 지배적인가를 알기 위하여 확산과 용해 항으로 조사하였다. $\mathrm{PEG}$ 400 의 함량이 증가함에 따라 모든 기체에 대한 투과도 및 이상선택도가 모두 증가하였다. 특히 $\mathrm{CO}_{2} / \mathrm{N}_{2}$ 의 경우 53.2( $\mathrm{PEG} 400$ 이 첨가되지 않은 $\mathrm{PEBAX} 1657$ )으로부터 84.1(PEG 400이 50\% 첨가된 막)이었으며, $\mathrm{SO}_{2} / \mathrm{CO}_{2}$ 는 38.9 에서 50.7, 그리고 $\mathrm{CO}_{2} / \mathrm{CH}_{4}$ 의 경우는 177.7 에서 31.4 의 결과를 보여주었다. 투과도와 선택도의 증가는 기체들의 용 해도로 인한 것이며, 특히 $\mathrm{CO}_{2}$ 와 $\mathrm{SO}_{2}$ 에 대해서는 더욱 증가한다는 것을 알 수 있었다. 수증기에 대한 내구성을 얻 기 위하여, glutaraldehyde(GA)가 PEBAX 1657/PEG 400 혼합막에 첨가되었다. 결과적으로 투과도는 혼합막에 있어 서 투과도 증가와 선택도 감소의 주된 요인으로 작용하는 자유부피와 ether oxide 기의 감소로 인하여 줄어들었으나 이는 막의 내구성을 향상시키는데 도움이 되었을 것으로 사료된다.
\end{abstract}

\begin{abstract}
Poly(ether-block-amide) 1657 (PEBAX 1657) blended membranes with molecular weight 400 poly(ethylene glycol) (PEG 400) were prepared and their permeability was tested for the gases $\mathrm{N}_{2}, \mathrm{O}_{2}, \mathrm{CH}_{4}, \mathrm{CO}_{2}$, and $\mathrm{SO}_{2}$ by the timelag method. The permeation characteristics were investigated in terms of diffusivity and solubility, which are dominant factors for gas transport. With the addition of PEG 400, the permeability of all the gases increased and also the ideal selectivity for several pair gases was enhanced. In particular, selectivity for $\mathrm{CO}_{2} / \mathrm{N}_{2}$ ranged from 53.2 (pristine PEBAX 1657 membrane) to 84.1 (50\% PEG 400 added), for $\mathrm{SO}_{2} / \mathrm{CO}_{2}$ from 38.9 to 50.7 , and for $\mathrm{CO}_{2} / \mathrm{CH}_{4}$ from 17.7 to 31.4 . The increase of both permeability and selectivity is mainly because of the increase of solubility of the gases, especially $\mathrm{CO}_{2}$ and $\mathrm{SO}_{2}$. To obtain durability against water vapor, glutaraldehyde (GA) was added to the PEBAX 1657/PEG 400 blended membranes. As a result, permeability decreased owing to a reduction of the free volume and ether oxide units, which are the main factors in elevating the permeability for the blended membranes, and selectivity decrease however; we believe that the durability of the resulting membranes would be increased.
\end{abstract}

Keywords: poly(ether-block-amide), poly(ethylene glycol), gas separation, $\mathrm{CO}_{2}, \mathrm{SO}_{2}$.

\section{Introduction}

Emissions of $\mathrm{SO}_{2}$ generated from fossil fuel combustion are common pollutants known to cause corrosion and acid rain, which is harmful to humans and the environment. ${ }^{1}$ To combat such emissions of sulfur oxides, there are strict regulations

${ }^{\dagger}$ To whom correspondence should be addressed.

E-mail: jwrhim@gmail.com implemented at coal and fuel power plants, including additional desulfurization (FGD, flue gas desulfurization) unit requirements, and there are many underway studies investigating the application of membranes in desulfurization processes.

The use of polymer membranes in sulfur dioxide separation has been investigated by many researchers and it has been shown that $\mathrm{SO}_{2} / \mathrm{CO}_{2}$ selectivity was in the range of 5-40 and that selectivity was not governed by diffusion as the kinetic 
diameter of $\mathrm{SO}_{2}$ was larger than that of $\mathrm{CO}_{2}{ }^{2}$ In addition, the increase of $\mathrm{SO}_{2}$ permeability results from the higher critical temperature, which could lead to a greater affinity constant and higher loading in the Langmuir free volume sites. ${ }^{2}$ Facilitated transport is another process for the separation of acidic gases that relies on a chemical reaction occurring between the gases of interest and a component of the polymeric membrane (carrier). In this facilitated transport, the acid(gases)base(active carrier) relationship increases the $\mathrm{SO}_{2}$ loading in the membrane because of the similar chemistry with $\mathrm{CO}_{2}$. Ionic liquids, ${ }^{3}$ diethanolamine, ${ }^{4}$ and sodium hydroxide ${ }^{5}$ have been used as carriers. In particular, $\mathrm{SO}_{2}$ permeability was measured for five imidazolium-based ionic liquids supported on polyethersulfone microfiltration membranes at temperatures from 25 to $45^{\circ} \mathrm{C}$ and at atmospheric pressure; and the selectivities of $\mathrm{SO}_{2} / \mathrm{CO}_{2}$ and $\mathrm{SO}_{2} / \mathrm{N}_{2}$ were 9-19 and 126-233, respectively, while $\mathrm{SO}_{2}$ permeability was in the range of 450011900 Barrer. $^{3}$

Poly(ethylene oxide) (PEO) has a special affinity for sour gases because of dipole-quadrupole interactions, and such membranes could be used selectively to remove acid gases from mixtures. ${ }^{6}$ As well as PEO and poly(ethylene glycol) (PEG), which has polar ether segments, are well known to interact with acid gases as shown by the enhancement of both $\mathrm{CO}_{2}$ permeability and $\mathrm{CO}_{2} / \mathrm{N}_{2}$ selectivity using blended PEG membranes with cellulose acetate or cellulose nitrate. ${ }^{7,8}$ In addition to PEO and PEG, rubbery segments such as sulfolane increase $\mathrm{SO}_{2}$ permeability with an increasing quantity of rubbery polymers. ${ }^{9-11}$

Poly(ether-block-amide) (PEBA), which is often used to separate polar and non-polar gases and performs well for high permeability and selectivity, ${ }^{12,13}$ is composed of polyamide (PA) for its hard glass segment and polyether (PE) for its soft rubber segment in the polymer chains, ${ }^{14}$ i.e., the crystalline amide block in PEBA functions as an impermeable phase, whereas the ether block in PEBA acts as a permeable phase because of its high chain mobility. Deng et al. ${ }^{15}$ reported very high $\mathrm{SO}_{2}$ permeability of 29976 Barrer and selectivity toward $\mathrm{N}_{2}$ of 23237 using a PEBAX 1657 dense membrane. Lee et al. ${ }^{16}$ investigated the separation performance of PEBAX 3533 coated onto polyetherimide hollow fiber membranes for $\mathrm{SO}_{2} /$ $\mathrm{CO}_{2} / \mathrm{N}_{2}$ mixed gas. $\mathrm{SO}_{2} / \mathrm{CO}_{2}$ selectivity was shown to be 5 to about 65 , while $\mathrm{CO}_{2}$ permeance was indicated in the range of 38 to 42 at various temperatures. Lee et al. ${ }^{13}$ reported the effect of the chemical composition and the morphology of PEBAX series copolymers on the permeation behavior of $\mathrm{CO}_{2} / \mathrm{N}_{2}$ and
$\mathrm{SO}_{2} / \mathrm{N}_{2}$ gas mixtures. Those concluded that the high permeability and selectivity were attributed to strong affinity of polyethers in PEBAX.

In this study, PEBA 1657, which is known to have high bonding strength to acid gases, was blended with PEG to enhance permeability and again with glutaraldehyde (GA) to improve permeation selectivity and durability. Upon producing the PEBAX/PEG and PEBAX/PEG/GA blended membranes, single gas permeation experiments were performed targeting for $\mathrm{N}_{2}, \mathrm{O}_{2}, \mathrm{CH}_{4}, \mathrm{CO}_{2}$, and $\mathrm{SO}_{2}$ by using the time-lag method to understand how diffusivity and solubility affect permeability of the resulting membranes. In addition, the effect of GA used as a crosslinking agent was investigated on permeability and permselectivity.

\section{Experimental}

Materials. A variety of poly(ether-block-amide) (PEBA, Atochem Inc.) are available depending on the ether block and amide block ratio. For the current study, we used PEBAX ${ }^{\mathrm{TM}}$ 1657 (PEBAX 1657, ether block 60\%). Additional poly(ethylene glycol) (PEG, M.W. 400, Aldrich Co.) (PEG 400), crosslinking agent glutaraldehyde (GA, 25\% solution, M.W. 101, Junsei Chemical Co. Ltd., Japan), and solvent ethanol (Junsei Chemical Co., Ltd., Japan) were used without undergoing any refinement processes. Pure water was prepared and purchased through Younglin Pure Water System (Seoul, Korea).

PEBAX 1657/PEG 400/GA Blended Membrane. The casting solution was prepared using $3 \mathrm{wt} \%$ of PEBAX 1657 in $70 \mathrm{wt} \%$ of ethanol uniformly mixed with pure water at $80{ }^{\circ} \mathrm{C}$ for $2 \mathrm{hr}$. PEG 400 was prepared and mixed into PEBAX 1657 at 20,40 , and $50 \mathrm{wt} \%$ to create the blended membranes, and additionally GA at various content levels of 3, 6, and $9 \mathrm{wt} \%$ was added to the mixed solution of PEBAX and PEG $50 \mathrm{wt} \%$ to improve durability of the membranes. The final solution was stirred for over $24 \mathrm{hr}$. Then, the solution was cast on a glass plate and dried for $3 \mathrm{hr}$ in a vacuum oven, resulting in the required blended membranes.

Gas Permeation Experiment. The gas permeation apparatus used in the experiment was based on the Integral Permeation (closed receiving volume) method and enabled measurements for single gas permeability. As shown by the gas permeation measurement results (Figure 1), typically, the transmission curve approaches a linear line after a certain time and parameters derived from the dotted (straight) line depicting 


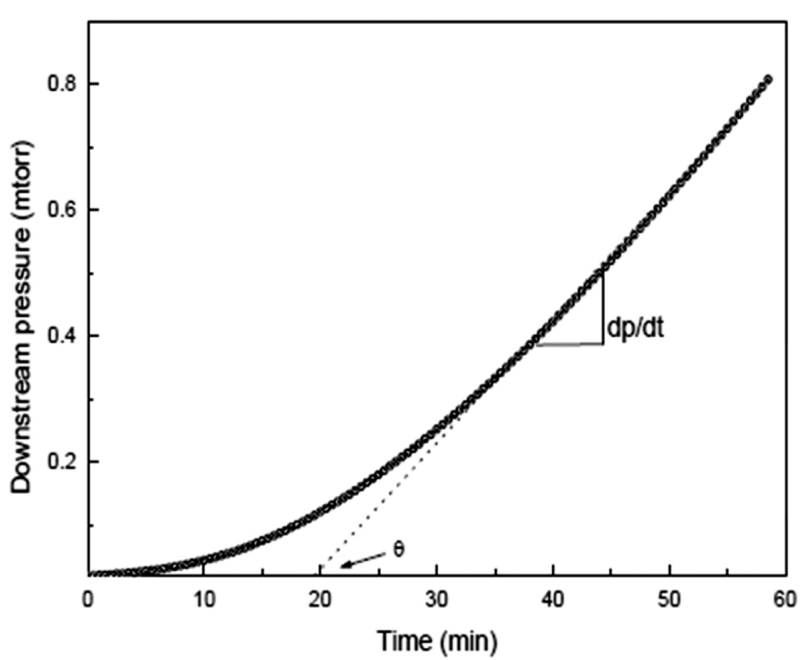

Figure 1. General results obtained from closed-volume permeation experiments.

the slope of the increase (permeability ratio) and time-axis intercept (time lag) are used to describe permeation experiments. $S$ (solubility) and $D$ (diffusivity) can be expressed using Henry's Law and Fickian's Law.

$P$ (permeability) can be computed from slope $(\phi)$ from Figure 1.

$$
P=\frac{\phi / A}{\Delta P / l}
$$

Then, time-lag $(\theta)$ can be measured by the following equation. Permeability $(P)$ is the product of solubility and diffusion coefficients.

$$
\begin{aligned}
& D=l^{2} / 6 \theta \\
& P=D \cdot S
\end{aligned}
$$

Gas Permeability Measurements. The time-lag device schematic used for the membrane gas permeability experiment is shown in Figure 2. First, the membrane is fixed between the permeable cells, which were centered with the surrounding layers maintained in a vacuum. Then, the gas is inserted into the above layer at $1 \mathrm{~atm}$. Once it fills the layer, the valve is opened so that the gas diffuses to the bottom layer owing to pressure differences. Hence, the gas is able to permeate through the membrane. The device maintains a constant temperature at $25^{\circ} \mathrm{C}$.

\section{Results and Discussion}

In general, the permeation properties of a gas are determined

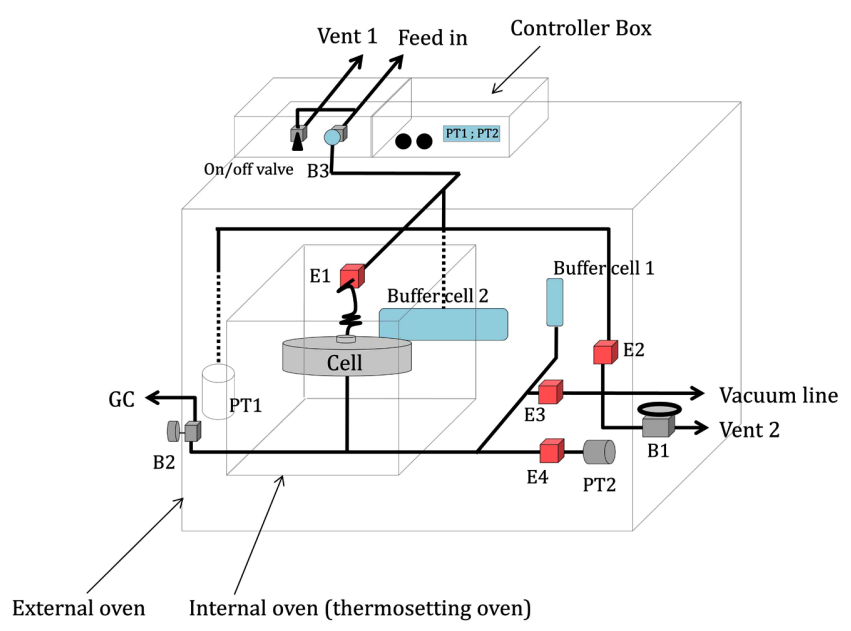

Figure 2. Apparatus for gas permeation process.

by its chemical nature, crystallinity, and morphology; ${ }^{13}$ however, for series of PEBAX copolymers, their permeation behavior is different from that of homopolymers and their properties with respect to the chemical composition and morphology. ${ }^{17}$

As PEG is known to show high permeation of $\mathrm{SO}_{2}$, the preparation of PEG blended membranes with series of PEBAX copolymers would be expected to provide a synergy effect in terms of separation efficiency as well as flux.,10 The permeability of PEBAX 1657 blended membranes with PEG 400 at various quantities of 20,40 , and $50 \mathrm{wt} \%$ was determined (Figure 3), and it was shown that the permeability of all the gases increased along with an increases of PEG 400. In case of the $\mathrm{N}_{2}, \mathrm{O}_{2}$, and $\mathrm{CH}_{4}$ gases, the upward trend of the permeability of each gas may be attributed to induction of a free volume (soft segment) increase through the addition of more PEG 400. On the other hand, for the sour and more condensable gases $\mathrm{CO}_{2}$ and $\mathrm{SO}_{2}$, the permeability of PEBAX itself is relatively high and the flux with PEBAX/PEG 400 becomes higher as PEG 400 is introduced. It is known that this may be due to an increase in the presence of ethylene oxide (EO) units and that both the free volume and the EO units affect flux complexly. ${ }^{15}$ From these results, it exhibited that gas transport of the non-condensable gases would be mainly governed by Fickian diffusion; however, from the figures, it is difficult to differentiate what is more dominant for flux enhancement and a more detailed discussion is provided below in terms of diffusivity and solubility measured by the time-lag method. Next the ideal selectivity in relation to the gas separation fields was described (Figure 4). In case the numerators are the sour gases, the selectivity of $\mathrm{CO}_{2} / \mathrm{CH}_{4}, \mathrm{CO}_{2} / \mathrm{N}_{2}$, and $\mathrm{SO}_{2} / \mathrm{CO}_{2}$ indicate 


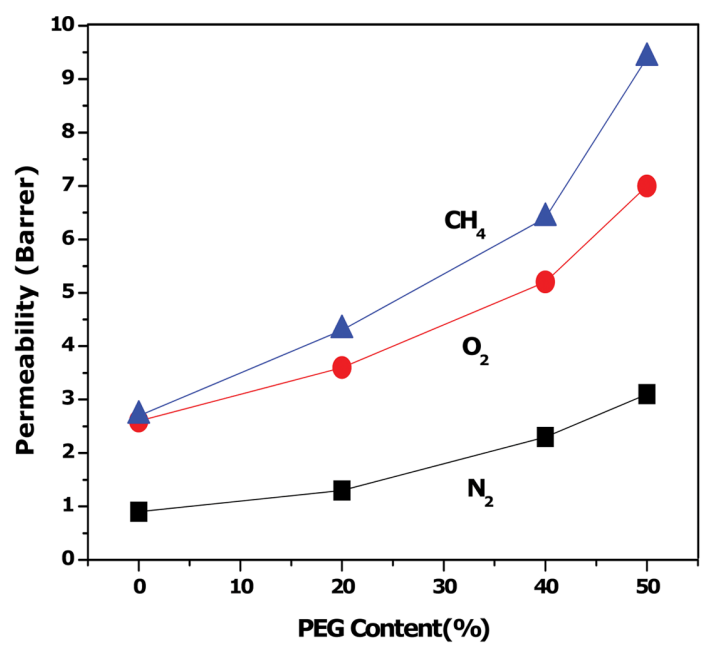

(a)

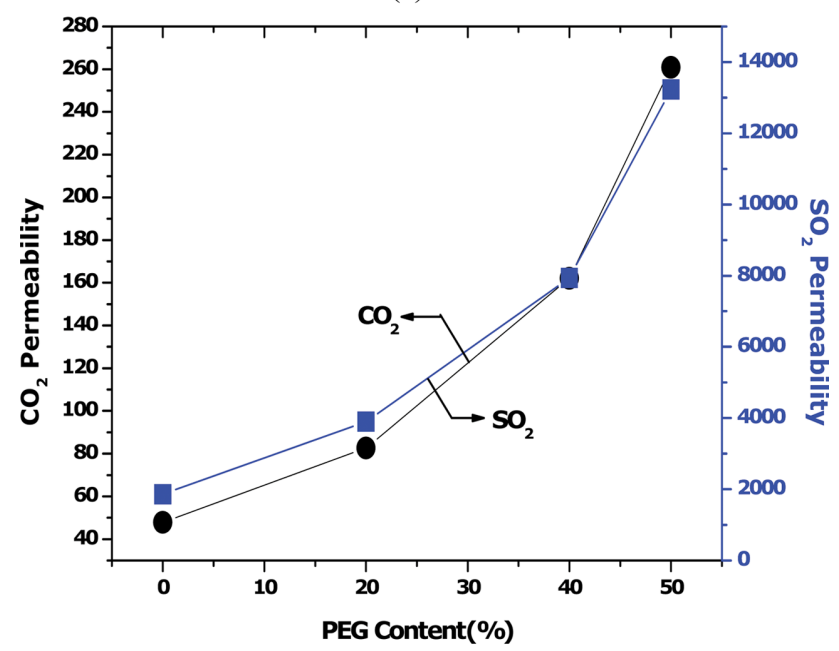

(b)

Figure 3. Gas permeability of PEBAX/PEG 400 blended membranes as a function of PEG content at $25{ }^{\circ} \mathrm{C}$.

enhancement trends, while the selectivity of $\mathrm{O}_{2} / \mathrm{N}_{2}$ shows no improvement as PEG 400 content increases. At PEG content of $50 \%$, the ideal selectivity obtained for $\mathrm{CO}_{2} / \mathrm{N}_{2}, \mathrm{CO}_{2} / \mathrm{CH}_{4}$, and $\mathrm{SO}_{2} / \mathrm{CO}_{2}$ was 84.1, 31.4, and 50.7, respectively.

From a comparison of the diffusivity and diffusivity selectivity of the gases in relation to PEG 400 content (Table 1), it

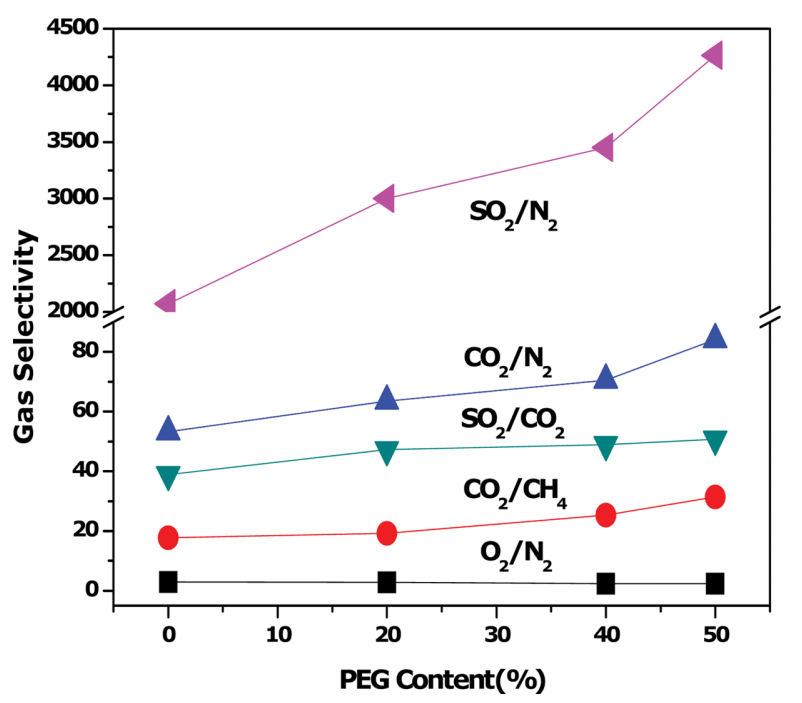

Figure 4. Gas selectivity of PEBAX/PEG 400 blended membranes as a function of PEG content at $25^{\circ} \mathrm{C}$.

is shown that diffusivity increases as the PEG 400 content increases. In particular, the diffusivity of $\mathrm{CH}_{4}, \mathrm{CO}_{2}$, and $\mathrm{SO}_{2}$, which are regarded as condensable gases, was almost two times higher at 50\% PEG 400 content in comparison with no addition of PEG 400, while the figures for $\mathrm{N}_{2}$ and $\mathrm{O}_{2}$ did not reach these values. It exhibited clear from these diffusivity measurements that the addition of PEG gave rise to an enhancement of diffusivity; however, for the condensable gases, it could be seen that there is another effect on diffusivity, and this will be discussed in detail in the solubility measurement section. The large to small sequence for diffusivity with no addition of PEG 400 was $\mathrm{O}_{2}>\mathrm{CO}_{2}>\mathrm{SO}_{2}>\mathrm{CH}_{4}>\mathrm{N}_{2}$; however, this sequence changes with the addition of 50\% $\mathrm{PEG}$ 400 to $\mathrm{CO}_{2}>\mathrm{SO}_{2}>\mathrm{O}_{2}>\mathrm{CH}_{4}>\mathrm{N}_{2}$ (There was a large gap between $\mathrm{CH}_{4}$ and $\mathrm{O}_{2}$ with $0 \%$ PEG 400, but this gap almost closed at $50 \%$ PEG 400.). It could be observed that the addition of PEG 400 is more favorable for the condensable gases. In most cases, there were no significant differences in the diffusivity selectivity for several gas pairs; thus, it can be seen that diffusivity does not influence separation or transport.

Table 1. Diffusivity and Diffusivity Selectivity for PEBAX/PEG 400 Blended Membranes

\begin{tabular}{cccccccccccc}
\hline & \multirow{2}{*}{$\begin{array}{c}\text { PEG } \\
(\mathrm{wt} \%)\end{array}$} & $\mathrm{N}_{2}$ & $\mathrm{O}_{2}$ & $\mathrm{CH}_{4}$ & $\mathrm{CO}_{2}$ & $\mathrm{SO}_{2}$ & $\mathrm{O}_{2} / \mathrm{N}_{2}$ & $\mathrm{CO}_{2} / \mathrm{CH}_{4}$ & $\mathrm{CO}_{2} / \mathrm{N}_{2}$ & $\mathrm{SO}_{2} / \mathrm{N}_{2}$ & $\mathrm{SO}_{2} / \mathrm{CO}_{2}$ \\
\hline & 0 & 3.21 & 7.58 & 3.61 & 5.28 & 4.92 & 2.4 & 1.5 & 1.6 & 1.5 & 0.9 \\
PEBAX/ & 20 & 3.61 & 8.00 & 6.22 & 7.01 & 6.09 & 2.2 & 1.1 & 1.9 & 1.7 & 0.9 \\
PEG400 & 40 & 4.04 & 8.39 & 6.81 & 8.08 & 8.10 & 2.1 & 1.2 & 2.0 & 2.0 & 1.0 \\
& 50 & 4.92 & 8.43 & 7.01 & 10.8 & 9.92 & 1.7 & 1.5 & 2.2 & 2.0 & 0.9 \\
\hline
\end{tabular}

*unit: $10^{-7} \mathrm{~cm}^{2} / \mathrm{s}$. 
Table 2. Solubility and Solubility Selectivity of PEBAX/PEG 400 Blended Membranes

\begin{tabular}{|c|c|c|c|c|c|c|c|c|c|c|c|}
\hline & \multirow{2}{*}{$\begin{array}{c}\text { PEG } \\
(w t \%)\end{array}$} & \multicolumn{5}{|c|}{ Solubility* } & \multicolumn{5}{|c|}{ Solubility selectivity [-] } \\
\hline & & $\mathrm{N}_{2}{ }^{* *}$ & $\mathrm{O}_{2} * *$ & $\mathrm{CH}_{4}{ }^{* *}$ & $\mathrm{CO}_{2}$ & $\mathrm{SO}_{2}$ & $\mathrm{O}_{2} / \mathrm{N}_{2}$ & $\mathrm{CO}_{2} / \mathrm{CH}_{4}$ & $\mathrm{CO}_{2} / \mathrm{N}_{2}$ & $\mathrm{SO}_{2} / \mathrm{N}_{2}$ & $\mathrm{SO}_{2} / \mathrm{CO}_{2}$ \\
\hline & 0 & 2.8 & 3.4 & 7.3 & 0.009 & 0.38 & 1.2 & 12.4 & 32.4 & 1352 & 41.8 \\
\hline PEBAX/ & 20 & 3.6 & 4.5 & 7.6 & 0.012 & 0.56 & 1.3 & 15.7 & 33.2 & 1542 & 46.4 \\
\hline \multirow[t]{2}{*}{ PEG400 } & 40 & 5.7 & 6.2 & 9.4 & 0.020 & 0.98 & 1.1 & 21.3 & 35.2 & 1614 & 48.9 \\
\hline & 50 & 6.3 & 8.3 & 1.2 & 0.024 & 1.33 & 1.3 & 20.5 & 38.3 & 2116 & 55.2 \\
\hline
\end{tabular}

$* \mathrm{~cm}^{3} /(\mathrm{STP}) / \mathrm{cm}^{3} \mathrm{cmHg} . * * \times 10^{-4}$.

From observation of solubility and solubility selectivity shown in the same manner as diffusivity (Table 2), it can be seen that the solubility of $\mathrm{N}_{2}$ and $\mathrm{O}_{2}$ was very small, while that of $\mathrm{CO}_{2}$ and $\mathrm{SO}_{2}$ was very large and $\mathrm{CH}_{4}$ lay in between. The trend of flux increase for all gases (Figure 3) arise from solubility rather than from diffusivity, and in particular the large quantities of $\mathrm{CO}_{2}$ and $\mathrm{SO}_{2}$ flux resulted from the remarkable solubility. It is known that diffusivity is a function of solubility; therefore, it may be considered that the increase in diffusivity along with increasing PEG 400 content also arises from the higher solubility. Although solubility increased for $\mathrm{N}_{2}$ and $\mathrm{O}_{2}$ as PEG 400 content increases, flux was not particularly high because of the very low solubility. For all the gases there was little difference in diffusivity; however, it is known that any distinguishable difference in flux is caused by solubility. Furthermore, gas separation efficiency is also shown to arise from solubility differences. For $\mathrm{N}_{2}$ and $\mathrm{O}_{2}$ gases, there was no difference in the increase ratio of both diffusivity and solubility. As a result, there was no separation even with the addition of PEG 400; however, it was much different for the $\mathrm{CO}_{2}$ and $\mathrm{SO}_{2}$ gases, i.e., their solubility was fairly high and increased by several times as the PEG 400 content increases. This eventually provided high selectivity in the $\mathrm{CO}_{2} / \mathrm{N}_{2}, \mathrm{SO}_{2} / \mathrm{N}_{2}$, and $\mathrm{SO}_{2} / \mathrm{CO}_{2}$ pair gases.

According to the Langmuir affinity constant, which is generally proportional to the critical temperature of the gas, the presence of water even in trace amounts in flue gases containing $\mathrm{CO}_{2}, \mathrm{SO}_{2}$, and $\mathrm{N}_{2}$ mixtures may give the dominant gas permeability because water has a very high critical temperature, $647.3 \mathrm{~K}$, which is much higher than that of any of the gases in this study. In addition, the blended PEBAX/PEG 400 membranes need to be tightened more because PEG 400 is water-soluble leading it to be "soluble" in humid and high temperature environments; therefore, it was decided to tighten the PEBAX/PEG $40050 \%$ blended membranes by the addition of GA so that the resulting membranes would be resistant to water through hydrogen bonding. According to our present

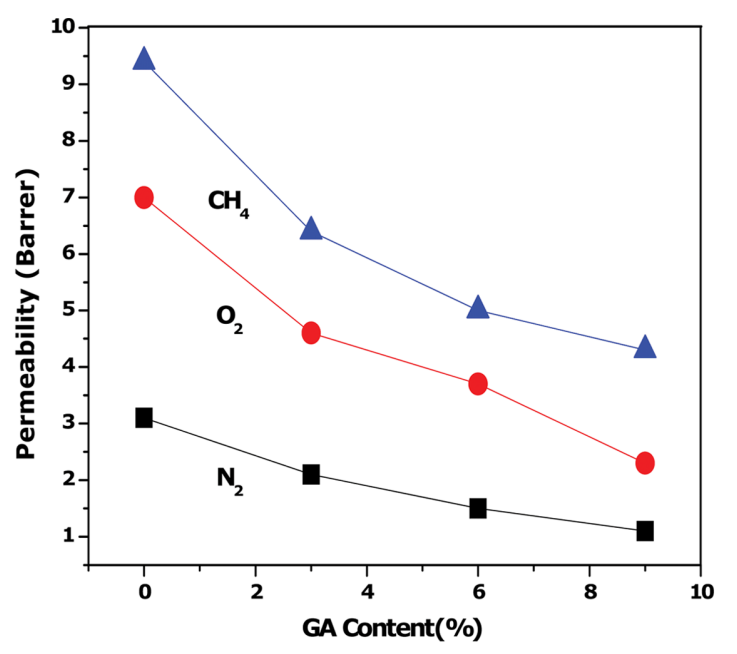

(a)

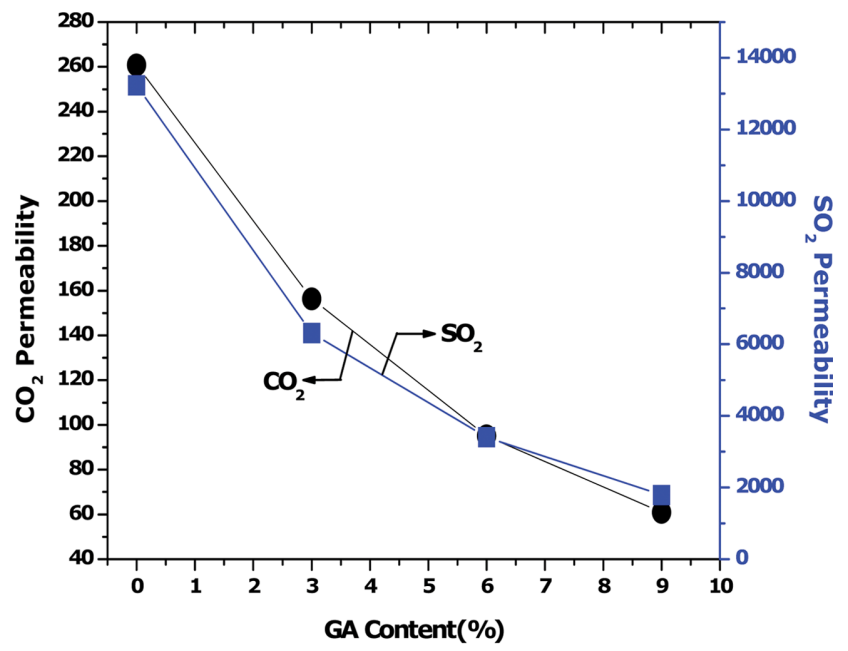

(b)

Figure 5. Gas permeability of PEBAX/PEG 400/GA blended membranes as a function of GA content at $25^{\circ} \mathrm{C}$.

study, it is expected that the addition of GA may lead to a reduction of flux resultant from the hydrogen bonding between the carbonyl group in the carboxylic acid and both polyethers in PEBA and hydroxyl groups in PEG since this hydrogen bonding leads the average free volume size and also the total 
fractional free volume; ${ }^{18}$ however, there is a need to know the amount of reduction of flux and how selectivity changes positively or negatively.

The permeability of each gas as a function of the GA content from 3 to 9\% in PEBAX/PEG 400 50\% (Figure 5) showed that permeability may be reduced because of the expected hydrogen bonding between the carboxylic acids and polyethers. The permeability of all the gases decreased along with an increase of GA content with declines of about half to one-third for $\mathrm{N}_{2}$, $\mathrm{O}_{2}$, and $\mathrm{CH}_{4}$ and one-fourth and one-sixth for $\mathrm{CO}_{2}$ and $\mathrm{SO}_{2}$ respectively. It is previously mentioned that the permeability of each gas was affected by both the free volume and EO units. In case of the addition of more GA into PEBAX/PEG 400, there was more hydrogen bonding formation between the EO units and carboxylic groups, resulting in rise to the average free volume size and simultaneously the total free volume fraction. ${ }^{18}$ The results also show that the addition of PEG also led to an increase in the permeability of $\mathrm{CO}_{2}$ and $\mathrm{SO}_{2}$ (Figure 5) and this might be due to an increase of the EO units; however, even if the GA did not react chemically, the properties of the pure EO units may be lost owing to the hydrogen bonds. Hence, the decline ratio of the permeability of $\mathrm{CO}_{2}$ and $\mathrm{SO}_{2}$ may be larger than that of $\mathrm{N}_{2}, \mathrm{O}_{2}$, and $\mathrm{CH}_{4}$. This bonding led to a tightening and more compact structure. As a result, both diffusivity and solubility may be reduced, and this will be discussed in more detail below.

Selectivity was depicted in the same manner as for PEBAX/

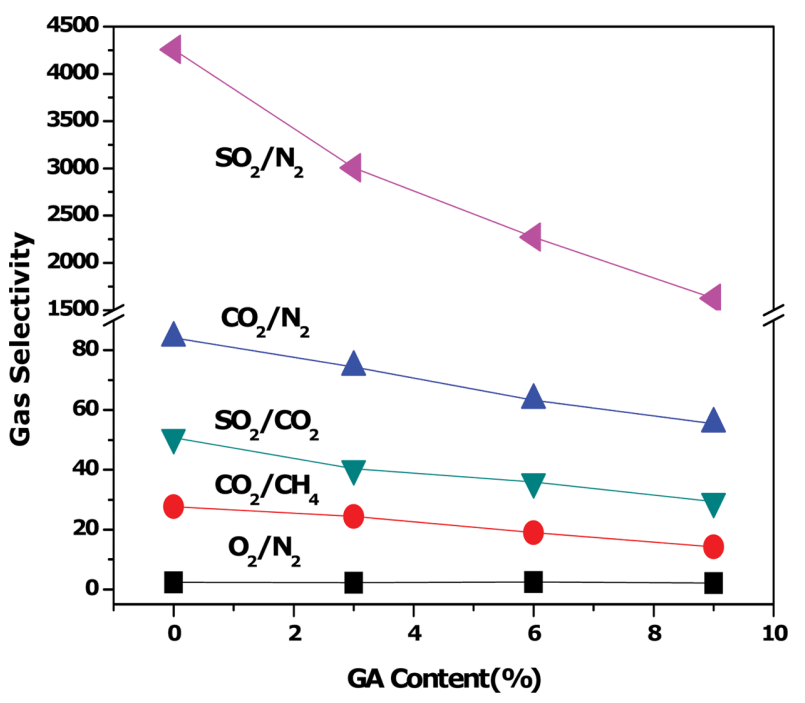

Figure 6. Gas selectivity of PEBAX/PEG 400/GA blended membranes as a function of GA content at $25^{\circ} \mathrm{C}$.

PEG 400 blended membranes (Figure 6), and Figure 6 shows a decrease of selectivity as a function of GA content. As discussed above, it was unexpected results because permeability is affected by the free volume and EO units.

Diffusivity declines with an increase of GA content while diffusivity selectivity shows no evident variation (Table 3 ), and the major cause of this was considered to be a reduction of the free volume because of the hydrogen bonding force. In other words, it seems that a part of the rubbery micro-domain may be changed to a glassy state because of the hydrogen bonding.

Table 3. Diffusivity and Diffusivity Selectivity of PEBAX/PEG 400/GA Blended Membranes

\begin{tabular}{|c|c|c|c|c|c|c|c|c|c|c|c|}
\hline & \multirow{2}{*}{$\begin{array}{c}\text { GA } \\
(w t \%)\end{array}$} & \multicolumn{5}{|c|}{ Diffusivity* } & \multicolumn{5}{|c|}{ Diffusivity selectivity [-] } \\
\hline & & $\mathrm{N}_{2}$ & $\mathrm{O}_{2}$ & $\mathrm{CH}_{4}$ & $\mathrm{CO}_{2}$ & $\mathrm{SO}_{2}$ & $\mathrm{O}_{2} / \mathrm{N}_{2}$ & $\mathrm{CO}_{2} / \mathrm{CH}_{4}$ & $\mathrm{CO}_{2} / \mathrm{N}_{2}$ & $\mathrm{SO}_{2} / \mathrm{N}_{2}$ & $\mathrm{SO}_{2} / \mathrm{CO}_{2}$ \\
\hline \multirow{4}{*}{$\begin{array}{c}\text { PEBAX/ } \\
\text { PEG400 } \\
(50 \mathrm{wt} \%) / \mathrm{GA}\end{array}$} & 0 & 4.92 & 8.43 & 7.34 & 10.8 & 9.92 & 1.7 & 1.5 & 2.2 & 2.0 & 0.9 \\
\hline & 3 & 5.00 & 7.67 & 7.16 & 8.33 & 7.91 & 1.5 & 1.2 & 1.7 & 1.6 & 0.9 \\
\hline & 6 & 3.85 & 6.92 & 7.01 & 7.07 & 6.51 & 1.8 & 1.0 & 1.8 & 1.7 & 0.9 \\
\hline & 9 & 3.62 & 5.67 & 6.90 & 6.11 & 5.07 & 1.6 & 0.9 & 1.7 & 1.4 & 0.8 \\
\hline
\end{tabular}

$* 10^{-7} \mathrm{~cm}^{2} / \mathrm{s}$.

Table 4. Solubility and Solubility Selectivity of PEBAX/PEG 400/GA Blended Membranes

\begin{tabular}{|c|c|c|c|c|c|c|c|c|c|c|c|}
\hline & \multirow{2}{*}{$\begin{array}{c}\text { GA } \\
\text { (wt\%) }\end{array}$} & \multicolumn{5}{|c|}{ Solubility* } & \multicolumn{5}{|c|}{ Solubility selectivity [-] } \\
\hline & & $\mathrm{N}_{2} * *$ & $\mathrm{O}_{2} * *$ & $\mathrm{CH}_{4}{ }^{* *}$ & $\mathrm{CO}_{2}$ & $\mathrm{SO}_{2}$ & $\mathrm{O}_{2} / \mathrm{N}_{2}$ & $\mathrm{CO}_{2} / \mathrm{CH}_{4}$ & $\mathrm{CO}_{2} / \mathrm{N}_{2}$ & $\mathrm{SO}_{2} / \mathrm{N}_{2}$ & $\mathrm{SO}_{2} / \mathrm{CO}_{2}$ \\
\hline \multirow{4}{*}{$\begin{array}{c}\text { PEBAX/ } \\
\text { PEG400 } \\
(50 \mathrm{wt} \%) / \mathrm{GA}\end{array}$} & 0 & 6.3 & 8.3 & 12.8 & 0.024 & 1.33 & 1.3 & 18.9 & 33.2 & 2116 & 55.2 \\
\hline & 3 & 4.2 & 6.0 & 8.9 & 0.019 & 0.80 & 1.4 & 21.1 & 44.7 & 1900 & 42.6 \\
\hline & 6 & 3.8 & 5.3 & 7.1 & 0.013 & 0.52 & 1.4 & 18.9 & 35.3 & 1376 & 39.0 \\
\hline & 9 & 3.0 & 4.1 & 6.2 & 0.010 & 0.35 & 1.4 & 16.1 & 33.2 & 1175 & 35.4 \\
\hline
\end{tabular}

$* \mathrm{~cm}^{3} /(\mathrm{STP}) / \mathrm{cm}^{3} \mathrm{cmHg} . * * \times 10^{-4}$. 
These glassy regions are impermeable and insoluble for the gases, even for non-condensable gases; therefore, diffusivity was first decreased by the more compact structure and then secondly by the reduction of solubility as diffusivity is a function of solubility. The solubility and solubility selectivity results (Table 4) also showed that the solubility of each gas decreased as GA increases.

\section{Conclusions}

In this study, first, poly(ether-block-amide) 1657 (PEBAX 1657) blended membranes with molecular weight 400 poly(ethylene glycol) (PEG 400) were prepared and their permeability tested for the gases $\mathrm{N}_{2}, \mathrm{O}_{2}, \mathrm{CH}_{4}, \mathrm{CO}_{2}$, and $\mathrm{SO}_{2}$ by the time-lag method. The permeation characteristics were investigated in terms of diffusivity and solubility, which are dominant factors for gas transport. With the addition of PEG 400 , the permeability of all the gases increased, and in particular permeability for $\mathrm{CO}_{2}$ and $\mathrm{SO}_{2}$ was enhanced by several times. Also the ideal selectivity for several pair gases was increased with the selectivity for $\mathrm{CO}_{2} / \mathrm{N}_{2}$ ranging from 53.2 (pristine PEBAX 1657 membrane) to 84.1 (50\% PEG 400 added), for $\mathrm{SO}_{2} / \mathrm{CO}_{2}$ from 38.9 to 50.7 , and for $\mathrm{CO}_{2} / \mathrm{CH}_{4}$ from 17.7 to 31.4 . The increase of both permeability and selectivity is mainly because of the increase of solubility of the gases, especially $\mathrm{CO}_{2}$ and $\mathrm{SO}_{2}$. To obtain durability against water vapor, glutaraldehyde (GA) was added to the PEBAX 1657/PEG 400 blended membranes. As a result, permeability decreased as hydrogen bonding led to a reduction of the free volume and ether oxide units, which are the main factors in elevating the permeability for the blended membranes. Unfortunately, selectivity also decreased; however, we believe that durability of the resulting membranes would increase because of the hydrogen bonding. With 3\% GA, there was a noticeable decrease in permeability for $\mathrm{CO}_{2}$ and $\mathrm{SO}_{2}$, while there was only a small decrease in permeability for $\mathrm{N}_{2}, \mathrm{O}_{2}$, and $\mathrm{CH}_{4}$.
Acknowledgement: This research was financially supported by the Ministry of Education (MOE) and National Research Foundation of Korea (NRF) through the Human Resources Training Project for Regional Innovation (No. 2013H1B8A2032261).

\section{References}

1. R. J. Heinsohn and R. L. Kabel, Sources and Control of Air Pollution, Prentice Hall, Englewood Cliffs, NJ, 1999.

2. C. A. Scholes, S. E. Kentish, and G. W. Stevens, Sep. Purif. Rev., 38, 1 (2009)

3. Y.-Y. Jiang, Z. Zhou, Z. Jiao, L. Li, Y.-T Wu, and Z.-B. Zhang, J. Phys. Chem. B, 111, 5058 (2007).

4. M. Okamota and A. Chakma, $\mathrm{SO}_{2}$ Separation by Reactive Liquid Membranes, Elserier, Amsterdam, 1994.

5. M. Teramoto, Q. Huang, T. Maki, and H. Matsuyama, Sep. Purif. Technol., 16, 109 (1999).

6. H. Lin and B. D. Freeman, J. Memb. Sci., 239, 105 (2004).

7. M. Kawakami, H. Iwanaga, Y. Hara, M. Iwamoto, and S. Kagawa, J. Appl. Polym. Sci., 27, 2387 (1982).

8. J. Li, K. Nagai, T. Nakagawa, and S. Wang, J. Appl. Polym. Sci., 58, 1445 (1995).

9. A. Sengupta, B. Raghuraman, and K. K. Sirkar, J. Memb. Sci., 51, 105 (1990).

10. D. L. Kuehne and S. K. Friedlander, Ind. Eng. Chem. Process Des. Dev., 19, 609 (1990).

11. D. L. Kuehne and S. K. Friedlander, Ind. Eng. Chem. Process Des. Dev., 19, 616 (1990).

12. V. I. Bondar, B. D. Freeman, and I. Pinnau, J. Polym. Sci., Part B: Polym. Phys., 38, 2051 (2000).

13. J. H. Kim, S. Y. Ha, and Y. M. Lee, J. Memb. Sci., 190, 179 (2001).

14. A. Car, C. Stropnik, W. Yave, and K. V. Pinemann, J. Memb. Sci., 307, 88 (2008).

15. X. Ren, J. Ren, and M. Deng, Sep. Purif. Technol., 89, 1 (2012).

16. K. Kim, P. G. Ingole, J. Kim, and H. Lee, Chem. Eng. J., 233, 242 (2013).

17. S. A. Stern, V. M. Shah, and B. J. Hardy, J. Polym. Sci., Part B: Polym. Phys., 25, 1263 (1987).

18. Q. M. Jia, M. Zheng, Y. C. Zhu, J. B. Li, and C. Z. Xu, Eur. Polym. J., 43, 35 (2007). 